\title{
Reformator i statysta albo hulaka na metafizyczna skale O dwóch portretach cara Iwana Groźnego w kinie rosyjskim
}

Zaiste niełatwo byłoby znaleźć kategorię, którą można byłoby opisać ciemność, jaka kryje się w zakorzenionym w kulturze wizerunku pierwszego cara Rosji. Czy można by go nazwać krwawym tyranem, a może szaleńcem folgującym swojej skłonności do okrucieństwa i erotomanii, człowiekiem ulegającym paranoi o zabarwieniu religijnym albo wreszcie hulaką na wielką skalę? Zapewne. Wszystkie te określenia wydają się właściwe, ale zarazem wszystkie tylko po części odpowiadają prawdzie. Po części, gdyż pojawić się może wiele innych, ale też dlatego, iż ów najgłębszy mrok ma swój silnie skontrastowany rewers - obraz mądrego statysty, władcy postępowego, budującego potęgę państwa rosyjskiego. Nic tu nie jest jednoznaczne i przesądzone, a skrajne pozycje okupują $\mathrm{z}$ jednej strony żywiąca się nade wszystko widowiskowymi reprezentacjami zła kultura popularna, a z drugiej - twarda ideologia państwowotwórcza. $\mathrm{W}$ różnych okresach każda $\mathrm{z}$ nich zdaje się oddziaływać $\mathrm{z}$ różną siłą. Oczywiście ta pierwsza przeważa w recepcji zagranicznej, druga zaś dotyczy przede wszystkim przestrzeni wewnątrzrosyjskiej.

Owa radykalna rozbieżność staje się tym łatwiejsza, im mniejsza lub mniej spopularyzowana jest rzetelna wiedza historyczna. A trzeba przyznać, że w świetle wątłych i wyraźnie nieobiektywnych źródeł postać cara Iwana IV jawi się cokolwiek mgławicowo, co skutkuje powstawaniem bardzo rozbieżnych koncepcji również wśród badaczy.

[1] Na temat źródeł m.in. A. Pawłow, M. Perrie, Iwan Groźny. Car i tyran, przeł. S. Kędzierski, „Bellona”, Warszawa 2008, s. 16-18.
ANDRZEJ SZPULAK

Współczesnych Iwanowi źródeł historycznych pozostało niewiele. Są to relacje gości zagranicznych oraz obszerna historia panowania Iwana autorstwa księcia Andrieja Kurbskiego, bliskiego współpracownika cara, napisana po jego ucieczce w granice Rzeczypospolitej i oddaniu się pod opiekę króla Zygmunta Augusta i służąca zatem propagandowym celom polskiego protektora. Zachowała się też, zresztą cenna, korespondencja między władcą Rosji a jego byłym poddanym. Źródła rodzime w ten czy inny sposób w znakomitej większości zniknęły w pożodze Wielkiej Smuty, a te, które są, pochodzą w rzeczywistości $\mathrm{z}$ wieku XVII, gdy nowa dynastia Romanowów starała się zdyskredytować twórcę imperium, posługując się między innymi metodą preparowania dokumentów[1].

Taka sytuacja nastręcza historykom trudności, powodując ciągłą możliwość podważenia nieomal każdej ich tezy. Jednocześnie jednak stanowi nie lada wyzwanie, które bez przerwy pobudza do działania kolejne ich pokolenia. Centrum zainteresowania stanowi oczywiście fenomen opryczniny i związanego z jej siedmioletnim trwaniem apogeum terroru. W badaniach od ich początku do najbliższej współczesności rysują się dwa kierunki odpowiadające zasygnalizowanej powyżej antynomii w postrzeganiu tak niezwykłej postaci historycznej i jej poczynań, w pewnej mierze nawet fundujące tę antynomię.

Pierwszy proponuje widzieć w Iwanie człowieka chorego psychicznie bądź - w łagodniejszej wersji - ulegającego pewnym problemom psychicznym. Od XIX wieku historycy, a także psychiatrzy, tworzą psychologiczne portrety władcy, w których dominuje przeświadczenie o jego paranoicznych skłonno- 
ściach[2]. Istotną rolę przypisują tu przeżyciom $\mathrm{z}$ dzieciństwa, które synowi szybko zmarłego kniazia Wasyla III[3] upłynęło w samotności pośród krwawych rozgrywek bojarskich, których ofiarą padła między innymi jego matka, wielka księżna, regentka Helena Glińska. Paranoja przejawiać się miała na kilka sposobów. Pierwszym była mania prześladowcza, skutkująca permanentnymi egzekucjami na domniemanych spiskowcach, wyprawami pacyfikacyjnymi (np. na Nowogród), ucieczkami, otaczaniem się tylko ludźmi całkowicie zależnymi i bezwzględnie wiernymi. Drugim - erotomania. „Sadyzm, rozwiązłość i występki seksualne, zinstytucjonalizowane w latach 1565-1572 - pisze Richard Hellie wskazują na erotomańskie przejawy paranoi" [4]. Trzecim wreszcie - megalomania. Objawy mogły nasilać się poprzez nadużywanie alkoholu i odkrytą podczas przeprowadzonego w roku 1963 badania szczątków cara bolesną chorobę kości.

Wielu badaczy, analizując dostępną wiedzę na temat władcy Rosji, nie podziela tak daleko idących opinii. Dystansują się oni od hipotezy choroby, dostrzegając jedynie znamiona pewnych problemów psychicznych. Definiują je jako podejrzliwość (uzasadnioną, ale często jednak przesadną), kapryśność, skłonność do użalania się nad sobą. W odniesieniu do gorączkowej aktywności seksualnej mówi się o „odruchu ucieczki” - fizycznego i psychicznego zdystansowania się od otoczenia.

Obrazu niezrównoważenia może już nie tylko psychicznego, ale też duchowego naszego bohatera dopełnia wątek religijny. Był on bez wątpienia teologicznym erudytą, o czym świadczy choćby odbyta w Moskwie zimą 1582 roku dysputa z papieskim legatem, jezuitą Antonio Possevino, w której za pomocą dobrze przygotowanych retorycznych wywodów bazujących na rzetelnej znajomości Biblii i tradycji Kościoła potrafił osiągnąć swoje cele[5]. Ale też funkcjonował on w ciągłym napięciu między motywowaną religijnie surowością obyczajów a skrajną rozwiązłością, między okrutną i najbardziej wymyślnym sposobem dokonaną zbrodnią a żarliwą pokutą i modlitwą za ofiary kaźni, wśród których nie brakło osób duchownych, między racjonalnymi i dalekowzrocznymi decyzjami politycznymi a bardzo rozwiniętą świadomością apokaliptyczną.

Drugi z kierunków badań historycznych każe widzieć cara realizującego spójny i konsekwentny plan konsolidacji i wzmocnienia państwa, wprowadzenia go na nowe tory rozwoju oraz upodmiotowienia w polityce europejskiej. Wskazuje na bynajmniej nie unikatową dla XVI wieku skalę terroru, przyrównując go do paryskiej nocy św. Bartłomieja, wojen religijnych w Niemczech czy też poczynań księcia Alby w Niderlandach. Pewien regres tego rodzaju widzenia rzeczy nastąpił w drugiej połowie XX wieku jako reakcja na jego ideologiczne zadekretowanie w okresie stalinizmu. Przez kilka dekad (lata 30.-50. XX wieku) historykom sowieckim wolno było dochodzić do konkluzji wyłącznie pozytywnych w odniesieniu do cara i jego działalności państwowotwórczej i zarazem postępowej. $\mathrm{W}$ ostatnich latach ten zrozumiały regres zdecydowanie osłabł, czego dowodem [jest] choćby niedawno wydana w Polsce monografia Andrieja Pawłowa i Maureen Perrie. Zresztą wpisanie badań historycznych na temat Iwana Groźnego w ideologiczne programy sięga w Rosji czasu sporów słowianofilów z okcydentalistami.

Rzecz jasna wielką wagę dla kształtowania powszechnej świadomości historycznej miały i mają edycje popularyzatorskie, publicystyka,

[2] Na temat tych badań szerzej patrz: ibidem, s. $12-16$.

[3] Niektórzy historycy rzeczywiste ojcostwo przypisują nie prawdopodobnie bezpłodnemu, zmarłemu w roku 1533 (Iwan miał trzy lata) kniaziowi, lecz domniemanemu kochankowi matki Iwana, wielkiej księżnej Heleny - Iwanowi Owczinie-Tieliepniewowi-Oboleńskiemu. Ibidem, s. 40 .
[4] Ibidem, s. 13.
[5] A. Andrusiewicz, Iwan Groźny, „Świat Książ- ki”, Warszawa 2006, s. 174-175. 
a obecnie również rozliczne publikacje internetowe. W mniejszym lub większym stopniu charakteryzują się one szukaniem wersji uproszczonych i najbardziej efektownych, dość swobodnym uzupełnianiem faktów, tanim psychologizmem, anachronizmem i relatywizmem w ocenach etycznych, epatowaniem widowiskowością i skalą zbrodni, poszukiwaniem faktów zgoła sensacyjnych albo przynajmniej takich ich interpretacji[6].

Jeśli w pierwszym zdaniu tego artykułu pojawił się problem kategoryzowania zła kojarzonego z postacią Iwana IV, to wiązał się on $\mathrm{z}$ wizerunkiem tej postaci utrwalonym właśnie w powszechnej świadomości, a co za tym idzie - w kulturze (również popkulturze), i to utrwalonym nade wszystko poza granicami Rosji.

$\mathrm{W}$ recepcji wewnętrznej wizerunek ten również rozpada się na dwoje. Podział przypomina ten zaobserwowany w badaniach historyków, tyle że jest bardziej radykalny, a towarzyszy mu duże ciśnienie ideologiczne i światopoglądowe. Nie ma tu miejsca na próby cieniowania - przeważa demonizacja lub idealizacja. Dowodzi tego choćby bardzo bogaty dorobek sztuki rosyjskiej, odnoszącej się do fenomenu osoby cara i jego czasów. Interesowało się nimi malarstwo (Wiaczesław Szwarc, Ilia Riepin), rzeźba (Mark Antokolski), literatura (Michaił Lermontow, Siergiej Sołowiow, Fiodor Dostojewski, Lew Żdanow, Walentin Kostyliew), teatr (Aleksiej Konstantynowicz Tołstoj, Aleksiej Nikołajewicz Tołstoj), opera (Piotr Czajkowski, Mikołaj Rimski-Korsakow, Siergiej Słonimski), muzyka (Siergiej Prokofiew) i wreszcie film (Siergiej Eisenstein, Paweł Łungin). Ogniskują one $\mathrm{w}$ sobie to zainteresowanie również dlatego, że dotykają newralgicznych punktów rosyjskiej tożsamości, jej wewnętrznego sproblematyzowania i obecnej w niej sprzeczności.

[6] Takim tropem idą nawet niektóre prace o ambicjach historycznych. Patrz: H. Troyat, Iwan Groźny. Krwawy twórca imperium, przeł. B. Przybyłowska, Wydawnictwo Amber, Warszawa 2005.
To rozdwojenie jest doskonale widoczne, gdy spojrzy się na dwa filmy, które staną się przedmiotem dalszych rozważań w tym artykule. Pierwszy to słynny, kanoniczny dla historii kina Iwan Groźny Siergieja Eisensteina. Dwie części planowanej trylogii zrealizowane zostały w latach 1944-1946, trzecia nie powstała. Kolejny utwór to nakręcony w roku 2009 Car Pawła Łungina. Nie polemizuje on bezpośrednio z wizją sprzed ponad sześciu dekad, ale świadomie kreuje odmienną, wchodząc w nieunikniony wobec rangi dzieła autora Strajku dwugłos. Zestawienie tych właśnie obrazów gwarantuje możliwość odkrycia istoty antynomiczności wizerunku interesującej nas postaci historycznej.

Iwan Groźny to film o wielkich aspiracjach artystycznych, doskonalący zainicjowaną w Aleksandrze Newskim (1938) koncepcję filmowego dramatu muzycznego, operujący rozbudowanymi środkami wyrazu, zyskujący w historii kina światowego status arcydzieła. Eisenstein należał do tych wyjątkowo nielicznych twórców, którzy potrafili skojarzyć w swych dziełach najwyższe wymagania sztuki z przekazem ściśle ideologicznym. Jedyny wyłom stanowią tutaj ostatnie partie historii pierwszego cara Rosji.

Obie części ostatniego Eisensteinowskiego dzieła tworzą spójny, ale nie całkiem jednorodny wizerunek władcy. Świadczyć o tym mogą odmienne ich losy w fazie weryfikacji ideologicznej. Dzięki tej spójności można jednak analizować ten wizerunek jako całość.

Najpierw zatem to, co na powierzchni kreacja wizualna, obarczona wieloma znaczeniami, zanurzona w nieco, zdawałoby się, wysłużonej poetyce typażu. $\mathrm{W}$ wystudiowanych pozach, dynamicznym ruchu ciała zastygającego i nagle się ożywiającego, w wyrazistej gestykulacji i mimice, $\mathrm{w}$ tonie wypowiedzi operującej donośnym, niskim głosem ujawnia się nader istotna część przekazu. A pamiętając, że mamy do czynienia z medium filmu, trzeba sprecyzować, iż to właściwie jego podstawa, bez której wszystkie inne elementy nie mogłyby poprawnie zafunkcjonować. 
Car jawi się w filmie jako postać potężna, rozsadzająca ramy świata, w którym się porusza, nieomalże rozpięta między niebem a ziemią. Symptomatyczne, pozwalające dobrze uchwycić tę właściwość byłoby porównanie trzech ujęć twarzy Iwana $\mathrm{z}$ trzech różnych fragmentów filmu. W scenie zdobycia Kazania widzimy ją w monumentalnym ujęciu na tle zachmurzonego nieba, w scenie opuszczenia Słobody Aleksandrowskiej - na tle korzącego się, klęczącego ludu i wreszcie w scenie gry w szachy - na tle monstrualnie wyolbrzymionego cienia globusa. Dla podkreślenia nadzwyczajności owej perspektywy ciało bohatera przybiera często sylwetkę lotną, ptasią. Ręce podniesione w górę, rozłożone i zawsze osłonięte ogromnymi, bufiastymi, przypominającymi skrzydła rękawami. Tułów pochylony do przodu. Głowa podniesiona w górę, ze spiczastą brodą, która staje się czymś na kształt dziobu, i „orlim” wzrokiem penetrującym najodleglejsze horyzonty. Sylwetka ta wykonuje często gwałtowne ruchy o wielkiej amplitudzie, jakby miała za chwilę już poderwać się do lotu. Towarzyszą tej kreacji natchnione, patetyczne przemowy, rysujące dalekosiężne wizje, objawiające prawdę o stanie otaczającej rzeczywistości, przestrzegające przed niewidocznymi zagrożeniami, a przy tym odwołujące sie do uczuć najbardziej wzniosłych. Wszystko to umieszcza bohatera w sferze pneumatycznej, a więc tyleż powietrznej, co duchowej. I nawet jeśli - biorąc pod uwagę ideologię, jakiej film jest wyrazicielem - byłby to tylko dialektyczny duch dziejów, to i tak przecież niezachwiana pozostałaby sugestia nieogarnialnego, wewnętrznego wymiaru wybitnej, tworzącej historię jednostki.

Istotna staje się - zwłaszcza biorąc pod uwagę stylistykę wynikającą z zastosowania typażu - konfrontacja takiego wizerunku Iwana $z$ innymi postaciami. Nie ma potrzeby zatrzymywać się na ciotce Jefrosinii, wcieleniu zła, małości, partykularności, egoizmu, skłonności do krwiożerczych intryg. Twarz ta jest aż nadto czytelna. Kuzyn Władimir, ewentualny konkurent do tronu, to słaby głupiec, bynajmniej nie pragnący władzy. Książę Kurbski - inteligentny, zdolny, ale wewnętrznie podgryzany przez ambicję i dlatego ostatecznie zamknięty w swoim wnętrzu, skupiony na własnej osobie. Król Zygmunt August - goguś, pajac, bufon, próżny, zarozumiały, lekceważący Rosję i jej kulturę, skłonny do urządzania wypraw krzyżowych, oczywista karykatura władcy. Filip Kołyczew - dumny, gwałtowny, nierozumiejący nowych czasów, z krwi i kości bojar. Wreszcie Maluta Skuratow zimny, przebiegły pochlebca o pospolitej twarzy, skwapliwy wykonawca „brudnej roboty”. Zapatrzony w dal Iwan nie słucha nawet wypowiadanych przez niego planów praktycznej realizacji carskich zamysłów. To Maluta bierze na siebie odpowiedzialność za konieczny terror, uwalniając od niej zajętego snuciem bardziej ogólnych wizji władcę. Nikt z owego korowodu nie może stać się rzeczywistym partnerem Iwana - ze względu nie tyle na rolę, jaką ten odgrywa, ile na jego osobiste cechy. To one są źródłem jego szlachetnej tragicznej samotności.

Postać nie jest, jako się rzekło, w pełni jednorodna. Iwan, jakkolwiek zawsze monumentalny, po pierwsze ulega wahaniom i słabościom, a po drugie - szczególnie w drugiej części filmu - pogrąża się w stanie moralnego otępienia, wiążącego się z permanentnym nadużywaniem władzy absolutnej. Pierwsza z tych okoliczności dopełnia idealistycznego obrazu cara. Sekwencja żalu po śmierci ukochanej żony Anastazji i zdradzie obdarzanego pełnym zaufaniem Andrieja Kurbskiego ukazuje głęboką emocjonalność cara, niezaspokojoną potrzebę bliskości innych osób, siłę, która pozwala przezwyciężyć wewnętrzny kryzys, czystość serca, która powoduje, że nie podejrzewa nikogo o zamach na życie młodej carycy. Także i w innych momentach widać to swoiste przełamanie obrazu człowieka o niezłomnej woli. Gdy Maluta opowiada o szczegółach akcji przeciw Kołyczewom, władca woła: „Jakim prawem to robisz, carze Iwanie?”. I dalej: „Niechby mnie ominął ten kielich". Jego osobista wrażliwość, również religij- 
na, $\mathrm{z}$ trudem dostosowuje się do okrutnej dziejowej konieczności. Zresztą poprzez sekwencję z dzieciństwa władcy ukazane zostają źródła tej wrażliwości.

W zasadzie można by się pokusić o cały katalog pozytywnych (z punktu widzenia potrzeb ideologicznych stalinowskiej propagandy) cech bohatera, tworzących parenetyczny wzór politycznego przywódcy, wśród których nader często przewijałby się ów rys wrażliwości:

1. Car wie, co trzeba zrobić, by na wieki zapewnić państwu siłę i stabilność. Jest wizjonerem i zarazem konsekwentnym praktycznym wykonawcą konkretnego planu. Stąd nieustanna i krwawa walka z nierozumiejącymi niczego prócz własnych interesów bojarami.

2. Car nie pragnie wojny. Posłom chana kazańskiego mówi: „Bóg widzi, że nie chcieliśmy wojny". Sprzeciwia się nadmiernemu okrucieństwu w walce, za które uznaje umieszczenie jeńców tatarskich na machinach oblężniczych. Wątek ten nawet tylko w kontekście filmu wydaje się cokolwiek nieautentyczny.

3. Car jest doskonałym wodzem, stosującym nowoczesne techniki walki. To on rozkazuje podłożyć proch pod mury broniącego się Kazania.

4. Car wierzy przyjaciołom i rodzinie. Ci jednakże, $z$ wyjątkiem Anastazji, zdradzają i pozostawiają go w osamotnieniu.

5. Car odrzuca zabobon, ale wierzy w uzdrawiającą moc relikwii. Jest zatem autentyczny w swej religijności (w trakcie trwającej wojny Stalin potrzebował poparcia Cerkwi).

6. Car jest dobrym gospodarzem i politykiem. Nawiązuje stosunki handlowe z Anglią, omijając niedostępny dla siebie Bałtyk.

Jest jeszcze jednak drugi z wspomnianych wymiarów niejednorodności tej postaci, a mianowicie wewnętrzne rozpasanie wynikające z nadmiaru władzy. Dobrze je widać w scenie uczty, a właściwie swego rodzaju bachanaliów, w które się ona zamienia, oraz

[7] A. Andrusiewicz, op. cit., s. 229-230. w scenie zabójstwa Władimira. Iwan z zimną krwią, już bez owej dawnej wrażliwości, wydobywa z celowo upitego kuzyna wiadomość o planowanym zamachu na swoje życie, a potem wydaje go na śmierć. Delektuje się zemstą i własną siłą. Jego ludzkie cechy podlegają więc pewnej degeneracji.

Taki obrót sprawy, stanowiący zresztą w całej twórczości Eisensteina rzadki wyłom w całkowitej, wynikającej z osobistych przekonań wierności linii Partii, wywołał opłakane skutki zarówno dla filmu (jego drugiej części), jak i reżysera. Stalin po obejrzeniu Spisku bojarów miał wypowiedzieć tylko jedno słowo: „smyt”' (pol. 'zmyć). Potem spotkał się z twórcami filmu, krytykując ich wizje Iwana jako nazbyt słabego, a opryczników jako oderwanych od ludu. Aż wreszcie podpisał artykuł, w którym wskazał wyłącznie pozytywną rolę szesnastowiecznego władcy. Nadmieniał też, że błędem historycznego - a także filmowego - Iwana było nieusunięcie wszystkich bojarów, co poskutkowało nieszczęściami okresu Wielkiej Smuty. 4 września 1946 roku opublikowano uchwałę KC WKP(b) gloryfikującą pierwszego cara Rosji. Film Eisensteina określono w niej jako „dziwnie podobny do Ku-Klux-Klanu" [7]. Zabroniono dystrybucji drugiej jego części. Trzeciej reżyser nie zdążył już zrealizować (umarł w roku 1948). Wykreowany przez niego wyidealizowany portret władcy z rysem realnych ludzkich dylematów oraz głęboko ukrytą, delikatną sugestią degeneracji w krwawego tyrana okazał się $\mathrm{w}$ warunkach jednoznacznej wykładni historii niemożliwy.

Moment, w którym powstał Car Łungina, ma zupełnie inną charakterystykę. Pozycja władzy w Rosji nie była aż tak oczywista, a w konsekwencji jej presja na poprawność ideologiczną przekazu artystycznego nie mogła być tak silna. Nowy ekranowy wizerunek Iwana Groźnego stworzony więc został w warunkach względnej swobody. Zaś fakt, że w warunkach współczesnej Rosji nie wszystko może być powiedziane wprost, chyba wyłącznie sprzyjał reżyserowi, gdyż wymusił na nim 
posługiwanie się językiem i retoryką unikającymi jednoznaczności.

Dwudziestopierwszowieczny car jest w swoim wyglądzie nieco bardziej realistyczny. Pojawiają się stroje z epoki. Nie ma owego wystudiowania gestu i mimiki, które u Eisensteina odgrywało niezwykle ważną rolę znaczeniotwórczą. Zresztą w ogóle utwór nie ma takich jak jego sławny antenat ambicji artystycznych, nie wynika $z$ tak oryginalnych i twórczych koncepcji. Jego poetyka niczym szczególnym się nie wyróżnia. Pozostaje jednak w tej nowej kreacji osobowej podobna wyrazistość. Aktorstwo Piotra Mamonowa, jako się rzekło, o wiele bardziej realistyczne[8] niż Nikołaja Czerkasowa, pozbawione monumentalności, uwolnione od wpisania w ściśle wykrystalizowaną wizję plastyczną, pozostaje jednak pełne wewnętrznego żaru i ekspresji o wysokiej amplitudzie emocji - od śmiechu do płaczu, od władczego poczucia pełnej kontroli po wybuchy lęku i niepewności - i, co za tym idzie, posługującej się strategią kontrastu. To oczywiście wpisanie się w bardzo silną tradycję rosyjskiej sztuki aktorskiej, co Mamonow czyni, nie będąc w najmniejszym stopniu zawodowcem.

Jeśli obraz postaci Iwana Groźnego w filmie wcześniejszym determinuje nade wszystko przekaz ideologiczny, to u Łungina na czoło wysuwają się treści duchowe. Widzimy Iwana w bezpośredniej relacji z Bogiem, w modlitwach i monologach czynionych bez pośrednictwa Kościoła i kapłanów. Iwan widzi siebie jako pośrednika między Bogiem a ludźmi, tego, który znajduje się najbliżej Stwórcy, momentami wręcz jako Jego wspólnika, uczestnika Jego władzy[9]. Dlatego funkcję i osobę patriarchy traktuje jako swoje narzędzie. Potrafi prowadzić subtelne dysputy religijne, takie jak ta, która odbyła się w ogrodzie metropolity Filipa, a dotyczyła kwestii przebaczenia. Ale taka rozmowa jest wyrazem łaski pomazańca Bożego, a nie wynikiem wewnętrznej potrzeby, a tym bardziej konieczności. Nad projektami państwowotwórczymi w umyśle cara górują wizje apokaliptyczne w duchu rosyjskiego mesjanizmu[10]. Stąd Nowe Jeruzalem - pałac zbudowany rękami dziewic.

Rozbudzona w Iwanie świadomość duchowego wyniesienia i niezwykłości rangi własnego powołania w czasach ostatecznych pozostaje w relacji z jego czynami. Uznaje on siebie za samodzierżawcę, pana życia i śmierci swoich poddanych, źródło okazywania woli Bożej względem nich. Jego władza ma absolutyzującą sankcję religijną. Jego terror i sadyzm także. Dotyczy to nawet erotomanii, której delikatna sugestia pojawia się w scenie chłostania dziewic. Prawem stanowionym przez człowieka staje się jego wola, prawo Boże zaś, o które upomina się Filip Kołyczew, w jego przekonaniu ma wobec niego relatywne zastosowanie.

W istocie jesteśmy jednak świadkami walki o duszę władcy. Z jednej strony staje dawny przyjaciel Filip, z drugiej pojawia się symboliczna postać błazna-diabła. Duchowa wrażliwość cara, a zapewne także wewnętrzne niezrównoważenie (raczej nie choroba), powoduje jego podatność również na zafałszowany obraz Boga. Są rzadkie momenty, kiedy uzyskuje on inne widzenie rzeczy, zgodne z rzeczywistym przesłaniem chrześcijańskim. Ale dzieje się tak na ogół wtedy, gdy opanowuje go strach, który przecież pragnie co prędzej od siebie odrzucić (nocna wizyta ducha zamordowanego Mit'ki Korbatowa). Car unika samotności, która na końcu jednak go dopada. Teatralizuje przemoc. Potrzebuje jej współuczestników i widzów (scena na arenie, sekwencja w przestrzeni wypełnionej maszynerią do torturowania - swoistym parku rozrywki). Drwi z ofiar (obiad z wojewodami,

[8] Można tak powiedzieć, biorąc przy tym pod uwagę zmianę konwencji aktorstwa filmowego, która nastąpiła w ciągu kilku dekad.

[9] Por. H. Troyat, op. cit., s. 116.

[10] Por. T. Špidlik, Myśl rosyjska. Inna wizja człowieka, przeł. J. Dembska, Wydawnictwo Księży Marianów, Warszawa 2000, s. 224-242, 266-276. 
głowa bratanka podana metropolicie Filipowi). Ucieka się do karnawalizacji (posadzony na tronie Filip ma sądzić wojewodów). Szuka porządku na opak, a właściwie stara się go tworzyć.

Rysując figurę władcy pogrążonego w duchowo pojmowanym złu, Paweł Łungin wykreował przesłanie duchowo-polityczne odnoszące się do historii, ale także współczesności swojego kraju. Filmowy Iwan to przecież spadkobierca tradycji „najpobożniejszych”, „równych apostołom” cesarzy bizantyjskich i stworzonej przez nich (VI Novella Justyniana) zasady symfonii współdziałających ze sobą władz świeckiej i duchownej. Tradycję tę władcy Rusi, a potem Rosji, przyjmowali coraz bardziej świadomie i coraz bardziej „po swojemu”. Ta swoistość wyraziła się w fakcie, iż metropolita moskiewski, przywódca rosyjskiego Kościoła, stał się w ręku Iwana już nawet nie narzędziem, a po prostu igraszką. Gdy uznaje to za właściwe, nawet w trakcie sprawowania liturgii każe on zerwać zeń insygnia (biały kłobuk) i szaty, a potem zawlec do więzienia, skazać na podstawie fałszywych zeznań i kazać zamordować mimo wyroku wygnania do klasztoru.

Zasada symfonii w swym założeniu polegała na zrównoważeniu mocy obu władz, zjednoczonych i współdziałających przede wszystkim dzięki tożsamości celu, jakim miało być doprowadzenie do zbawienia ludzi[11]. Władcy Rosji, począwszy od Iwana, rozumieli ją bardzo praktycznie. Władca stał się w tych warunkach "prawosławnym carem”, niejako ojcem-igumenem imperium. Państwo przeradzało się w wielki monastyr[12]. Doszło więc do supremacji władcy jako pierwszego po Bogu, opiekuna Kościoła. Posłuszeństwo i miłość względem cara stają się metafizycznie

[11] P. Evdokimov, Kobieta i zbawienie świata, przeł. E. Wolicka, „W drodze”, Poznań 1991, s. 128.

[12] T. Špidlik, op. cit., s. 182.

[13] Por. ibidem, s. 184.

[14] Ibidem, s. 185-186. ugruntowaną powinnością, także powinnością biskupów. Do takiego widzenia rzeczy odwołuje się reżyser.

Cały filmowy dramat męczeństwa Filipa Kołyczewa wpisany zostaje w tę bardzo trwałą wizję i zarazem strukturę myślową i wyobrażeniową. Metropolita nie neguje istoty zwierzchniej władzy cara. Nie ma tu mowy ani o buncie w imię zmiany porządku ustrojowego, ani o podjęciu walki o osobisty prymat. On korzysta z przynależnego ludziom Kościoła, choć z czasem coraz rzadziej wykorzystywanego, prawa do upominania świeckiego władcy[13], doprowadzając je do ostateczności wypowiedzenia posłuszeństwa carowi, który sprzeniewierzył się swemu powołaniu. Słysząc groźbę Iwana, odpowiada słowami: „Chrystus z nami. Kogo mamy się bać”. Odwołuje się zatem do argumentu ściśle duchowego.

Wspomniany wymiar polityczny filmu Łungina ma ostrze nie tylko antystalinowskie, o czym gremialnie wspominają recenzenci, ale także antyputinowskie. Również współczesny przywódca Rosji korzysta bowiem - w innych już oczywiście uwarunkowaniach - ze spuścizny bizantyjskiej symfonii, starając się symbolicznie sankcjonować swoją pozycję, a ponadto wykorzystywać Kościół do swoich pragmatycznych celów. Tymczasem reżyser, heroizując postawę świętego (rzeczywiście kanonizowanego w XVII wieku) męczennika, odrzuca całą tradycję cezaropapistyczną, demaskując jej przerażające skutki - podporządkowanie przesłania duchowego celom ściśle doczesnym.

Nie czyni tego z punktu widzenia zachodniego liberalnego demokraty. Sięga po świadomość obecną w rosyjskim prawosławiu od wieków, ale bardziej ukrytą[14], świadomość niemożności realizacji ideału chrześcijańskiego państwa w ramach historii. Ten swoisty krytycyzm wobec zasady symfonii, także jako wrogiej naczelnej dla Rosjan idei soborowości, nasilił się pod koniec XIX i w XX wieku. Wtedy to w sposób bezpośredni sformułowana została zasada antynomiczności władzy świeckiej i duchownej, ich odmienności. 
Wskazano też na istnienie granic posłuszeństwa wobec władzy świeckiej[15]. To jest właśnie źródło Łunginowskiego widzenia rzeczy. A widzenie to obejmuje właściwie pełne doświadczenie historyczne Rosji, szczególnie relacji państwo-Kościół. Jest w nim Iwan Groźny mordujący metropolitę Filipa, ale jest także Piotr I jako twórca formalnego cezaropapizmu, jest czas renesansu teologiczno-filozoficznego spod znaku Sołowiowa czy Bierdiajewa, jest i palący cerkwie Stalin, a wreszcie, jako się rzekło, chętnie przybierający symbolicznie postać cara Putin. Widzenie to ma właśnie perspektywę duchowo-polityczną.

Zestawienie tych dwóch filmowych portretów szesnastowiecznego władcy Rosji wpisuje się znakomicie w owo zarysowane na począt$\mathrm{ku}$ rozdwojenie widzenia tej postaci w badaniach historycznych oraz obiegu kulturowym. Istotną nowością jest może tylko to, iż Łungin, kreując zdecydowanie mrocznego Iwana, przesuwa akcent $\mathrm{z}$ choroby psychicznej na duchową.

Co ciekawe, to rozdwojenie obecne jest w całej pełni także w recepcji postaci Rurykowicza przez Kościół rosyjski. W odradzającej się ludowej tradycji prawosławnej car Iwan IV Wasiljewicz coraz częściej zajmuje miejsce w panteonie świętych. Jego ikony znajdują się w cerkwiach, są noszone podczas procesji i przez pielgrzymów. Postulaty o jego kanonizację stały się na tyle głośne, że w tej sprawie wypowiedział się moskiewski patriarcha Aleksiej II (zmarły w roku 2008). Stwierdził on, przypominając osobę swego świętego poprzednika sprzed wieków, Filipa Kołyczewa, i zbrodnię na nim popełnioną, że nie można postawić na jednej płaszczyźnie ofiary i jej kata[16]. W rezultacie zatem w rosyjskim dyskursie historycznym każdy ma swojego Iwana Groźnego. Mają go nacjonaliści, apologeci państwa jako takiego, liberałowie, demokraci, komuniści czy prawosławni o głębokim zaangażowaniu religijnym. Od tej instrumentalizacji pamięci i wyobraźni nie są wolni także artyści. Użyteczność dyskursywna tej postaci historycznej bierze górę nawet nad potężnym potencjałem jej demonicznej widowiskowości.

[15] Ibidem, s. 186-187.

[16] A. Andrusiewicz, op. cit., s. 231.

\section{Historia zespołów filmowych $z d z i s i e j s z e j$ perspektywy}

\section{Uwagi wstępne}

Zaproszenie do wzięcia udziału w łódzkiej konferencji[1], skierowane kilka miesięcy temu pod moim adresem przez prof. Tadeusza Szczepańskiego, przyjąłem bez chwili wahania, kierując się nadzieją, że porozmawiamy o zespołach filmowych w perspektywie doniosłości ich historycznego dorobku, ale też z należytą dozą krytycyzmu zarówno w odniesieniu do tego, co było, jak i tego, co istnieje obecnie. To drugie, czyli spojrzenie krytyczne, jest o wiele trudniejsze, lecz warte zbiorowej próby podjęcia przez uczestników spotkania, z natury rzeczy zainteresowanych analizą mechanizmów praktyki twórczej w naszej kinematografii.

W centrum naszej uwagi znajdą się cztery, powiązane z sobą, praktyczne aspekty tytułowego tematu: jak było? jak jest? jak mogłoby być? i jak być nie powinno? Celowo

[1] Referat wygłoszony na otwarcie ogólnopolskiej konferencji naukowej „Idea zespołu filmowego - historia i nowe wyzwania”, zorganizowanej przez Wydział Organizacji Sztuki Filmowej PWSFTViT w Łodzi w dniach 16-17 maja 2013 roku. 